Acta vet. scand. $1977,18,308-315$.

From the Department of Medicine, College of Veterinary Medicine, Helsinki and the Department of Serology and Bacteriology, State Veterinary Medical Institute, Helsinki, Finland.

\title{
LABORATORY DIAGNOSIS OF CANINE PYOMETRA
}

\author{
By \\ A-K. Kivistö, H. Vasenius and M. Sandholm
}

\begin{abstract}
KIVISTö, A-K., H. VASENIUS and M. SANDHOLM: Laboratory diagnosis of canine pyometra. Acta vet. scand. 1977, 18, 308-315. The principal laboratory test used to confirm the pyometra diagnosis in the bitch has been the determination of the total white blood cell count in venous blood. A marked elevation is known to be a characteristic of the disease.

In the present study, the white blood cell count was determined as well as the $\gamma$-globulin level. An elevation of the $\gamma$-globulin level and the total white blood cell count was very characteristic to the pyometra patients. The increase in the number of white blood cells nor the high $\gamma$-globulin level cannot be regarded specific for pyometra, therefore it was regarded important to find out a more specific test for pyometra.

When sonicated E. coli bacteria were tested against sera from pyometra patients in electroimmunodiffusion, the precipitation was almost always detected when E. coli had been isolated from the uterus. This technique provides a quick method in detecting the causative E. coli infection.

The present study suggests that whenever laboratory tests are used to confirm the pyometra diagnosis by the total white blood cell count, it is advantageous to analyze the total $\gamma$-globulin level in the serum as well as specific antibodies against a common E. coli antigen.

Because of the reliability of the glutaraldehyde coagulation test and the simple technique, this can be suggested as the method of choice for an average small animal practice.
\end{abstract}

canine pyometra; E. coli; gammaglobulins; immunochemical methods.

It is generally accepted that endocrine disturbances are the primary factors responsible for canine pyometra, and bacteria, usually E. coli, are secondary invaders of the uterus (Teunissen 1952, Dow 1959, Brodey \& Fidler 1966). 
The pyometra diagnosis is generally based on a detailed history: anorexia, vaginal discharge, polydipsia, polyuria, combined with a history of recent oestrus.

Succesful treatment depends on early detection of the disease, which may require supporting methods, such as X-ray. However, in the early stages of the disease the interpretation of the X-ray pictures is not very easy. The study of the blood picture may be very helpful in detection of pyometra. A marked elevation of the total white blood cell count has been shown to be the most characteristic changed parameter in pyometra (Whitney 1956, 1969, Schalm 1965).

Bacterial isolations of the purulent discharge have generally been positive. The $\mathrm{E}$. coli is the most commonly found invader (Asheim 1965).

It is known that enteric E. coli bacteria do not give rise to high levels of circulating antibody nor a urinary tract infection. On the other hand elevated E. coli antibodies have been observed as a result of pyometra (A sheim).

Blood serum from pyometra infected bitches has been shown to contain a precipitating antibody against the $\mathrm{E}$. coli strain isolated from the uterus of the patient itself. However, no cross reaction was obtained against different $E$. coli strains isolated from other uterine infections (Åsheim).

E. coli strains associated with genital tract infections in the bitch have been shown to belong to different serogroups (Wilkinson 1974). Recently a thermolabile antigenic factor was detected common to all the $E$. coli strains isolated from the uterine content (Sandholm et al. 1975). This made it possible to develop a general method for the detection of an E. coli antibody. This structure was observed to be responsible for the binding of the E. coli on the brush border of the endometrium during the luteal phase which is probably important for the colonization of the bacteria in the uterus (Sandholm et al.).

The present investigation was undertaken to develop a serologic test for screening for pyometra and to compare its effectiveness with existing laboratory tests. The object was to analyze the increase of the total $\gamma$-globulin by the glutaraldehyde test (Sandholm \& Kivistö 1975) as well as a specific E. coli antibody by immunological techniques in order to evaluate their effectiveness in screening for pyometra. 


\section{MATERIAL AND METHODS}

The study was based on 100 pyometra patients hysterectomized or necropsied at the Small Animal Clinic at the College of Veterinary Medicine, Helsinki during 1972-1974. The diagnosis was based on the enlarged uterus containing pus observed during laparatomy.

The bitches with only a slightly enlarged uterus (endometritis, endometric hyperplasia) were not included in the material.

\section{White blood cell count}

The EDTA-blood samples were diluted 1:20 with $3 \%$ acetic acid and calculated in a Bürker haemocytometer under microscope.

\section{Glutaraldehyde test}

Twenty $\mu$ l of $6 \%$ glutaraldehyde was mixed with $200 \mu$ l of serum at $22^{\circ} \mathrm{C}$ with a Cyclomixer (Clay-Adams), and the coagulation time noted. The $\gamma$-globulin concentration was extrapolated from the standard curve (Fig. 1).

Determination of antibodies against disintegrated E. coli by electroendosmosis

Preparation of antigen. An E. coli strain isolated from a pyometra patient was spread in saline on a blood-agar plate $\varnothing 8 \mathrm{~cm}$ and incubated overnight at $37^{\circ} \mathrm{C}$. The bacteria were suspended in $3 \mathrm{ml}$ of $0.02 \mathrm{M}$ barbital buffer, $\mathrm{pH}$ 8.6. Fifty $\mu$ l of Triton X 100 was added and the material disintegrated by sonication. The sonicated material was used as such for the antigen purpose.

Preparation of the agar gel. An equal amount $(0.125 \mathrm{~g})$ of agarose (Agarose A 37, L'Industrie Biologique Française) and purified agar (Difco) was melted in $20 \mathrm{ml}$ of $0.02 \mathrm{M}$ barbital buffer, pH 8.6, in a boiling water bath. The melted solution was poured on a $10 \times 20 \mathrm{~cm}$ glass plate and allowed to solidify in a humid chamber. When the agar had solidified, $\varnothing 6 \mathrm{~mm}$ holes were punched in the agar $1.5 \mathrm{~cm}$ apart.

Counter-current electrophoresis. The wells thus formed were filled: those along the anode with pyometra and control sera and the others with the sonicated bacteria. The antibodies in the test 


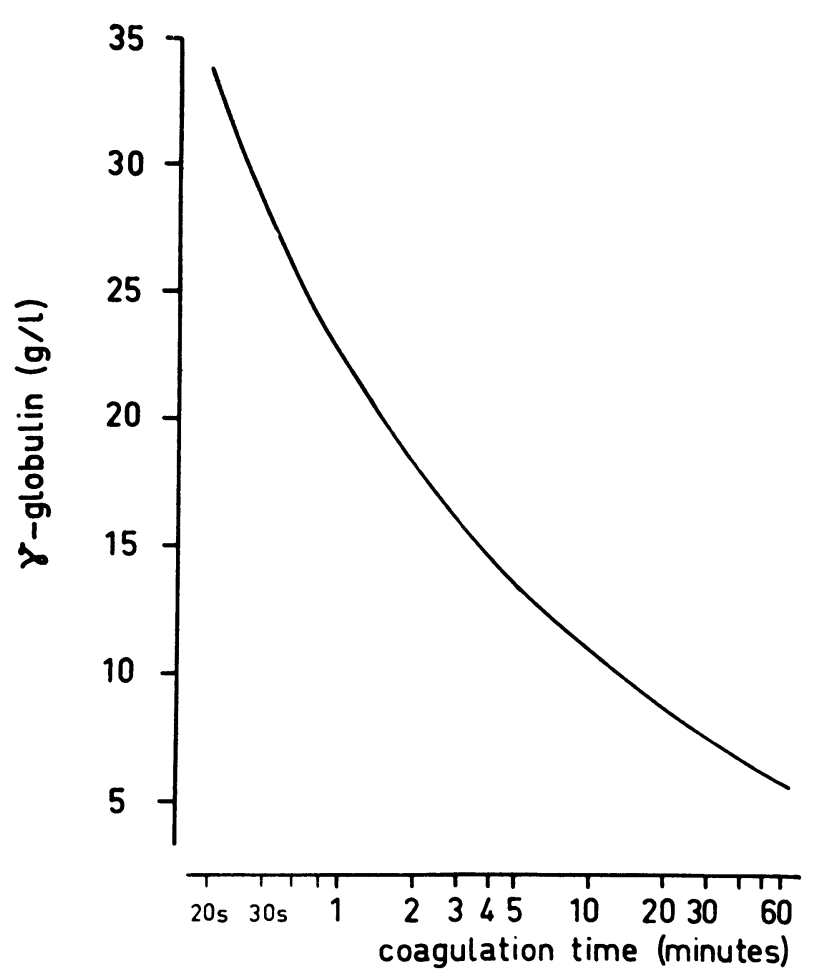

F ig u re 1. Standard curve for the determination of the $\gamma$-globulin level in dog serum.

Performance of the test: $20 \mu \mathrm{l}$ of $6 \%$ glutaraldehyde is mixed with $200 \mu \mathrm{l}$ of serum at room temperature in a test tube and the coagulation time noted by tilting the tube. The coagulation time correlates with the $\gamma$-globulin level according to the standard curve.

sera and the bacterial antigen were forced against each other in a potential gradient of $5 \mathrm{v} / \mathrm{cm}$ for $60 \mathrm{~min}$. after which the plate was examined under oblique light. The test was deemed positive when a clear precipitate was seen between the wells (Fig. 2).

\section{White cell count}

\section{RESULTS}

There was generally a marked increase in the total white cell count in the peripheral blood. The average white blood cell count in pyometra patients was $33,700 \pm 15,900$ (normal values about $10,000 / \mathrm{mm}^{3}$ (Schalm 1965)). 


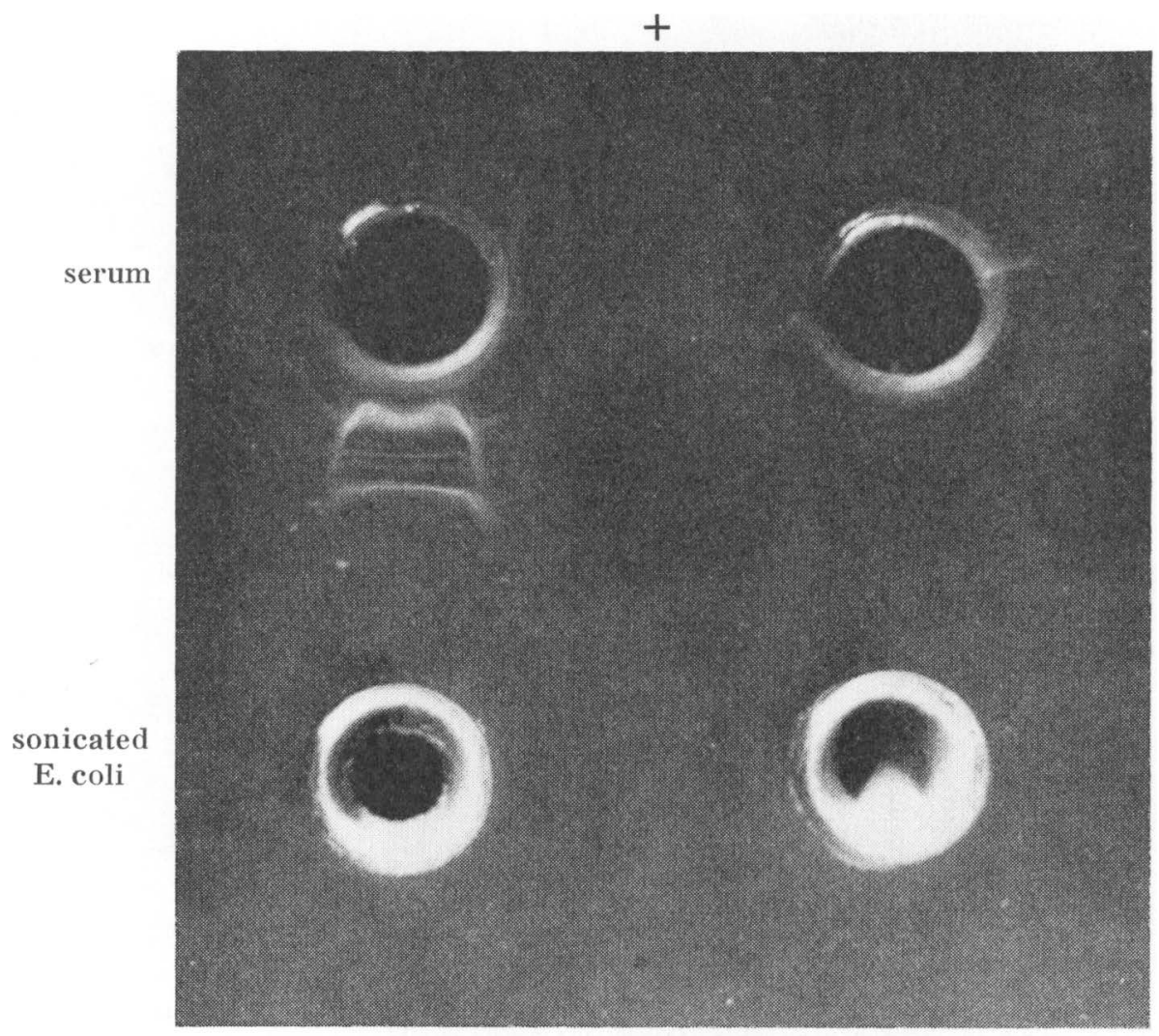

F igure 2. Counter-current electrophoresis for the detection of E. coli antibodies in sera from pyometra patients. The serum antibody and the disintegrated E. coli bacteria are forced against each other in an electric field. A positive result (precipitation) can be seen to the left.

\section{Glutaraldehyde test}

The $\gamma$-globulins were significantly increased in all pyometra cases which led to very short glutaraldehyde coagulation times. The average $\gamma$-globulin level was $26.3 \pm 3.9 \mathrm{~g} / \mathrm{l}$. When this range $( \pm s)$ is extrapolated to the coagulation time, a range is observed from 25 to $60 \mathrm{sec}$. (Normal sera coagulate between 3 and 100 min. which corresponds to a $\gamma$-globulin value of $3-15 \mathrm{~g} / \mathrm{l}$ ) (Sandholm \& Kivistö 1975). 
Presence of E. coli antibody by counter-current electrophoresis

The precipitation band was obtained in $93 \%$ of the cases when E. coli had been isolated from the uterine pus ( $85 \%$ of all cases). Other bacteria isolated were Streptococci (4\%), Staphylococci (2\%), Proteus sp (1\%), Pseudomonas sp (2\%), Aerobacter sp ( $3 \%)$. The dogs infected with other bacteria than E. coli did not show any antibody against E. coli antigen (with exception of three dogs with Aerobacter and one with Pseudomonas) nor any of the 61 control dogs suffering from other internal disorders than pyometra.

\section{DISCUSSION}

The present investigation introduces two new laboratory tests for serum, which seem to be very helpful as diagnostic aids when screening for pyometra.

The $\gamma$-globulin increases very markedly during the pyometra process. The $\gamma$-globulin can be measured from the serum in these instances usually in less than $1 \mathrm{~min}$. by the glutaraldehyde test used (Sandholm \& Kivistö 1975).

The increase can be explained to be caused by the stimulation of antibody producing lymphoid cells by material from the invading bacteria. This is probably true as antibodies against E. coli appeared in counter-current electrophoresis during E. coli infection of the uterus.

The immunoglobulins are catabolized mainly by the liver. Failure in this catabolism therefore results in an increase in the blood $\gamma$-globulin content. It is known that the liver function in pyometra patients is decreased, for example the use of barbiturate results in a prolonged narcosis. Some of the increase in $\gamma$-globulin is certainly due to a delayed catabolism.

The enteric E.coli bacteria do not generally give rise to specific antibodies in the sera, which is explained by the fact that antigens carried by portal circulation to the liver by-passes the immunological system (Prytz et al. 1974). This relatively insensitive antibody detection system gives positive results during pyometra indicating an effective antibody production in the course of the disease. Nor was cystitis induced by E. coli observed to give rise to precipitation (unpublished results). Antibody against $E$. coli material could be found in $83 \%$ of the pyometra cases. Most of the E. coli strains isolated gave a posi- 
live immunoprecipitation by any of the positive pyometra sera when analyzed by the counter-current electrophoresis (Sandholm et al. 1975). A similar method has been shown to give positive results by capsular material of E. coli (Semjen et al. 1977). Therefore it can be presumed that the pathogenic E. coli strains causing pyometra must have a common capsular antigen. The counter-current analysis seems to be useful in the detection of pyometras infected with enteric bacteria. Others, however, will not show up in this screening test.

It is our suggestion that when the pyometra diagnosis is confirmed using laboratory tests, the total white blood cells should be counted and the total $\gamma$-globulin concentration should be analyzed. The demonstration of $\mathrm{E}$. coli antibody is very helpful but this requires laboratory facilities.

\section{REFERENCES}

Brodey, R. S. \& I. J. Fidler: Clinical and pathologic findings in bitches treated with progestational compounds. J. Amer. vet. med. Ass. 1966, 149, 1406-1415.

Dow, C.: Experimental reproduction of the cystic hyperplasia-pyometra complex in the bitch. J. Path. Bact. 1959, 78, 267-278.

Prytz, H., M. Bjфrneboe, T. Stæhr Johansen \& F. Ørskov: The influence of portosystemic shunt operation on immunoglobulins and Escherichia coli antibodies in patients with cirrhosis of liver. Acta med. scand. 1974, 196, 109-112.

Sandholm, M. \& A-K. Kivistö: Determination of $\gamma$-globulin in dog serum by glutaraldehyde. J. small Anim. Pract. 1975, 16, 201205.

Sandholm, M., H. Vasenius \& A-K. Kivistö: Pathogenesis of canine pyometra. J. Amer. vet. med. Ass. 1975, 16, 1006-1010.

Schalm, O. W.: Veterinary Hematology. 2nd Ed. Lea \& Febiger, Philadelphia 1965, p. 204, 519-521.

Semjen, G., I. Ørskov \& F. Ørskov: K-antigen determination of Escherichia coli by counter-current immunoelectrophoresis (CIE). Acta path. microbiol. scand. Sect. B. 1977, 85, 103-107.

Teunissen, G. H. B.: The development of endometritis in the dog and the effect of oestradiol and progesterone on the uterus. Acta endocr. (Kbh.) 1952, 9, 407-420.

Whitney, J. C.: Pyometra in the bitch (with special reference to the pathology of the condition). Brit. vet. J. 1956, 112, 25-30.

Whitney, J. C.: Polydipsia and its relationship to pyometra. J. small Anim. Pract. 1969, 10, 485-489. 
Wilkinson, G. T.: O-groups of E. coli in the vagina and alimentary tract of the dog. Vet. Rec. 1974, 94, 105.

Asheim, Å.: Pathogenesis of renal damage and polydipsia in dogs with pyometra. J. Amer. vet. med. Ass. 1965, 147, 736-745.

\section{SAMMANFATTNING}

Diagnosticering av pyometra hos tik.

Blodprov från 100 tikar med pyometra analyserades i laboratoriet för att få fram en pålitlig metod att säkerställa pyometradiagnosen. Det beskrivs två nya metoder som är tillförlitligare än den klassiskt använda metoden att påvisa ett förhöjt antal vita blodkroppar i blodet. Den sistnämnda metoden är relativt ospecifik och kan ge förhöjda värden även vid många andra infektioner och myeloproliferativa sjukdomar.

Påvisandet av antikroppar mot E. coli med counter-current elektrofores gav positivt resultat i $85 \%$ av fallen. En tydlig hypergammaglobulinemi förekom alltid hos tikar lidande av pyometra. Denna hypergammaglobulinemi kan påvisas enkelt med glutaraldehydreagens, som koagulerar serumet desto snabbare ju starkare hypergammaglobulinemin är. Glutaraldehydreaktionen kan rekommenderas som rutinundersökning vid misstanke på pyometra.

(Received March 22, 1977).

Reprints may be requested from: A-K. Kivistö, the Department of Medicine, College of Veterinary Medicine, F-00 550 Helsinki 55, Finland. 